\title{
En tipunktsplan for bedre rettspsykiatri
}

\author{
Rettsforhandlingene etter terroren 22. juli er avsluttet og norsk rettspsykiatri er gjenstand for debatt som aldri \\ før. I denne debatten savner vi en prinsipiell drøfting av strafferettslig rettspsykiatri og dagens utilregnelighets- \\ regler. Vi foreslår her ti konkrete tiltak til forbedring av rettspsykiatrisk virksomhet. Men gratis blir det ikke.
}

I kjølvannet av rettsforhandlingene har det oppstått en skarp debatt om rettspsykiatriens plass i rettsvesenet. De rettspsykiatrisk sakkyndiges erklæringer om Anders Behring Breiviks tilregnelighet og Den rettsmedisinske kommisjons behandling av erklæringene har fått gjennomgå. Mange, både journalister, samfunnsvitere, politikere, jurister, psykologer og psykiatere, kritiserte den første erklæringen der tiltalte ble vurdert som utilregnelig. Da den neste erklæringen konkluderte med at Breivik derimot var tilregnelig, slo flere aviser opp at to erklæringer med ulik konklusjon i en så alvorlig sak var et symptom på rettspsykiatri i «krise»

Flere har kritisert rettspsykiatrien for ikke å holde faglig mål. En del av kritikken bør tas på alvor og vi mener det er god grunn til å drøfte endringer for å bedre standarden på, og rammevilkårene for, rettspsykiatrisk sakkyndighet (1). Vurderinger som gjøres kan få store konsekvenser for den som utredes. Derfor er det viktig at feltet baserer seg på forskningsbasert kunnskap om vurderingsmetodikk. Vi må se på faglige tradisjoner på nytt og kanskje legge bort stolthet knyttet til faglig posisjon, erfaring og status quo i feltet.

Vi presenterer en tipunkts liste som et utgangspunkt for en konstruktiv debatt om norsk rettspsykiatri. Listen er delt i tre hovedkategorier: metode/standardisering, organisatoriske rammebetingelser og lovmessige rammebetingelser.

\section{Metode og standardisering}

Punkt 1: Gullstandard. Vi foreslår å innføre bruk av mer standardiserte og vitenskapelig aksepterte utrednings- og testmetoder. Det kan være sjekklister, personlighetsundersøkelser og evneundersøkelser, avhengig av hvilken sak de sakkyndige skal utrede. Det er underlig at man i Norge, sammenliknet med andre nordiske land, synes å slå seg til ro med at man i de fleste tilfeller kan klare seg med en relativt enkel utredning, som for det meste består av samtaler med observanden. Det er ikke nedfelt noen regler for hvordan en rettspsykiatrisk undersøkelse skal foregå, dette er basert på tradisjon. Sammenliknet med de andre skandinaviske landene benytter Sverige seg av flest tilleggsundersøkelser (sjekklister, tester, somatiske undersøkelser) etterfulgt av Danmark og til sist Norge (2).
Punkt 2: Fagfelleråd. Det bør nedsettes et råd med medlemmer som har god kompetanse på utredning og vurdering innen rettspsykiatri, spesielt diagnostikk, personlighetsvurdering og risikovurdering. Mandatet bør særlig være å gjennomgå hva som finnes av egnet utredningsverktøy samt foreslå standarder for rettspsykiatriske utredninger. Rådet bør lage et sett med anbefalinger der forventninger til de sakkyndige og anbefalt bruk av utredningsmetoder klart fremkommer. Anbefalingene bør justeres regelmessig, gjerne i samarbeid med personer som er aktive som sakkyndige.

Punkt 3: Spesialitet. For å sikre høyere standard på sakkyndigarbeid kan man tenke seg innføring av spesialiteter eller underspesialiteter i sakkyndighet for både psykologer og psykiatere. Dette vil innebære systematisk kursing etterfulgt av godkjenning for å kunne utføre sakkyndighet.

\section{Ytre, organisasjonsmessige rammebetingelser}

Punkt 4: Organisatorisk tilknytning. Rettspsykiatri er i dag ikke tilknyttet noe institutt eller fagenhet som har ansvar for rekruttering, retningslinjer, akkreditering eller annen fagutvikling. Vi foreslår at rettspsykiatri bør få en organisasjonsmessig ramme slik som de andre rettsmedisinske grenene. Organiseringen bør tydeliggjøre tverrfagligheten i feltet der deler av rettspsykologien utgjør en naturlig del av rettspsykiatrien.

Punkt 5: Rettspsykiatriske klinikker. Observasjon bør gjøres i standardiserte miljøer, for eksempel rettspsykiatriske klinikker eller poliklinikker. Standardiserte betingelser og utredninger vil bedre muligheten for å gjøre grundige undersøkelser og dermed begrense mulige feilkilder. I dag må sakkyndige reise rundt i fengsler, psykiatriske sykehus, observandens hjem eller møte observanden på sitt eget kontor. Sakkyndige gjør dessuten alt tidkrevende administrativt arbeid i form av innhenting av opplysninger og skrivearbeid. Hovedoppgaven bør være utredning av observanden. Andre yrkesgrupper kan bistå med å samle inn viktig bakgrunnsinformasjon, som det gjøres bl.a. ved svenske og danske klinikker. I Sverige og Finland har man egne klinikker med innleggelse, i Danmark har man poliklinikker.

Punkt 6: Innsyn. Sakkyndige bør få automatisk tilgang til journaler og helseopplys- ninger. Dette bør nedfelles i lov/forskriftsendring gjeldende for alvorlige saker hvor konsekvensene av uriktig domfellelse er størst. Med alvorlige saker menes her saker med strafferamme over seks år, hvor saken administreres av en embetsdommer og hvor ankesaken automatisk vil kunne føres for lagmannsretten. Sakkyndige har i dag ikke tilgang til journaldokumenter uten observandens samtykke, slik man har i Sverige og Danmark ved alvorlige saker. Risikoen for feilvurderinger, pga. manglede premisser som journaler etc., er klart til stede i de tilfeller hvor observanden nekter å gi innsyn i helseopplysninger.

\section{Lovmessige rammebetingelser}

Punkt 7: Utilregnelighetsbegrepet. I dag er det, etter straffeloven $\S 44$, tre tilstander som gjør at en person kan bli kjent utilregnelig og derved anses som skyldfri av retten: hvis vedkommende er psykotisk, bevisstløs eller psykisk utviklingshemmet i høy grad. Vi foreslår en innsnevring av utilregnelighetskriteriet i straffeloven $\S 44$ til kun å omfatte to grupper: Den første gruppen inkluderer en kjernegruppe som har en klar realitetsbrist i form av uttalt psykose, og den andre gruppen vil fortsatt omfatte personer med alvorlig psykisk utviklingshemning. Vi ser det ikke hensiktsmessig å inkludere bevissthetsforstyrrelser da vårt inntrykk er at det er uensartet bedømming av slike tilstander og at de forekommer svært sjelden. En innsnevring vil kunne gjøre det lettere for fagdommere og legdommere å vurdere de sakkyndiges råd til retten. Det vil både kunne innebære a) at flere personer gis det menneskeverd det innebærer å stå til ansvar for sine handlinger og $b$ ) at den innflytelse eller makt som rettspsykiatere og rettspsykologer beskyldes for å ha i retten blir redusert.

Punkt 8: Innføring av blandet/psykologisk prinsipp. Norge har hatt det medisinske prinsipp siden 1929 (3, 4). Konsekvensen av det medisinske prinsippet er at personer som anses som psykotiske $\mathrm{i}$ henhold til straffeloven $\S 44$, automatisk vil bli ansett som utilregnelige. Med andre ord er det likegyldig hvorvidt gjerningsmannen har vært klar over handlingens straffbarhet for å avgjøre tilregnelighet. Det virker urimelig at en person automatisk skal anses som skyldfri fordi han har en gitt psykose, men hvor psykosen ikke har direkte sammenheng med det gjerningspersonen har gjort. 
En innføring av det psykologiske eller det blandede prinsipp vil innebære en konkret vurdering i hvert enkelt tilfelle. Enten kan man innføre et tilleggskriterium der det spørres om tiltalte i tillegg til å ha en psykoselidelse visste hva vedkommende gjorde og/eller at handlingen var gal. Dette vil nærme seg the M'Naghten rule som benyttes i mange engelskspråklige land. Eventuelt om tiltaltes straffbare handling hadde en sammenheng med den psykiske lidelsen, som vil tilsvare det psykologiske prinsipp. En innføring av et tilleggskriterium vil antakeligvis medføre at færre blir ansett som utilregnelige.

Punkt 9: Endring av mandatet. De sakkyndige skal som regel vurdere om observanden var psykotisk, bevisstløs eller psykisk utviklingshemmet i høy grad. I tillegg skal de vurdere om observanden hadde en sterk bevissthetsforstyrrelse, var lettere utviklingshemmet eller hadde nedsatt evne til realistisk vurdering av omverdenen, som gir mulighet for straffereduksjon etter straffeloven $\S 56 \mathrm{c}$. Som regel blir de sakkyndige også spurt om å vurdere prognose og risiko for nye straffbare handlinger, som gir retten veiledning om hvilken reaksjon som skal idømmes.

Vi mener mandatet bør endres for å innføre et klarere skille mellom det de sakkyndige skal svare på og det retten skal svare på. Det vil gi retten et mer uavhengig juridisk beslutningsgrunnlag. Dette kan gjøres på flere måter. En måte er å gi de sakkyndige i oppgave å vurdere om observanden oppfyller et sett med kliniske kriterier knyttet til de mest alvorlige sinnslidelsene i ICD-10, uten å skulle oversette inn i straffelovens juridiske begreper slik det er i dag. Retten må da selv oversette fra psykologiske/medisinske/psykiatriske begreper til juridiske kategorier som passer inn i straffelovens utilregnelighetskriterier. En annen måte er å beholde dagens mandat, men endre spørsmålet retten skal besvare, eksempelvis i retning av det man gjør i Danmark. Der skal de sakkyndige gi råd om spesifikke tilstander er til stede - i form av sinnssykdom (primært psykotiske tilstander) og så skal retten beslutte om de anser tiltalte for å være tilregnelig eller utilregnelig. Slik sett blir det et juridisk og språkmessig skille mellom a) det de sakkyndige skal vurdere (sinnssykdom) og b) det retten skal ta stilling til (tilregnelighet). Et slikt skille har vi ikke i Norge hvor de sakkyndige først vurderer og gir retten råd om observanden var psykotisk (samt de andre utilregnelighetskriteriene). Deretter vurderer retten bevisverdien i de sakkyndiges råd og om den er enig med de sakkyndige $i$ at vedkommende var psykotisk på handlingstiden eller ikke.
Punkt 10: Vurdering fra Den rettsmedisinske kommisjon. Kommisjonen bør, når de kvalitetssikrer erklæringene, gi en kortfattet, men tydelig vurdering av innholdet og konklusjonen i erklæringen. Standardformuleringen er i dag, om det ikke er innvendinger at «Det er ingen (vesentlige) bemerkninger til erklceringen». Slike korte formuleringer kan gi grobunn for usikkerhet med hensyn til hvordan kommisjonen har tenkt og vurdert. Kommisjonens vurdering bør skje etter eksplisitte kriterier på en standardisert måte for å unngå tvil om det de skal formidle. Når Rettslegerådet i Danmark gjennomgår erklæringer, kommer de med en skriftlig vurdering (de gjennomgår kun erklæringene hvor de sakkyndige mener at observanden er utilregnelig). Fordelen med slik kriteriebasert vurdering er todelt. For det første får retten en innsikt $i$ hvordan kommisjonen har tenkt og en eventuell uenighet $i$ kommisjonen kommer til syne. For det andre viser forskning på beslutningsteori at tilbakemelding er avgjørende for at fagfolk kan lære av og justere sine vurderinger. Slik kan man $i$ beste fall unngå fremtidige skjevheter og feilvurderinger (5).

\section{Avrunding}

Vi mener våre forslag er nødvendige for å øke kvaliteten på det sakkyndige arbeidet og dermed å øke rettssikkerheten for dem som blir vurdert. Innføring av standarder kan redusere risiko for feilbedømninger. $\AA$ etablere en organisatorisk tilhørighet og egne klinikker vil bedre arbeidsbetingelsene til de sakkyndige og derved redusere risiko for feilbedømninger. Dette er foreløpige forslag, andre forslag kan komme til. Noen vil kanskje savne et punkt om forskning, men vi mener at det i store trekk blir ivaretatt ved landets tre kompetansesentre for sikkerhets-, fengsels- og rettspsykiatri.

En klar konsekvens av de ovennevnte tiltakene er en mer ressurskrevende rettspsykiatri. Men rettssikkerhet koster, og vi mener derfor dette er underordnet de prinsipielle problemstillingene.

Det har vært mange utredninger i form av offentlige utvalg, høringer og lovendringer. Kanskje er det på tide med mer konkret handling, også fra politisk hold? Er politikerne villig til å ta konsekvensen av ønsket om forbedringer og endringer i rettspsykiatrien - også ved å bevilge penger og bedre rammevilkår? Det koker da ned til hvor høyt vi ønsker å prioritere bedre rettssikkerhet.

\section{Pål Grøndahl}

pagron@kompetanse-senteret.no

Cato Grønnerød

Ulf Stridbeck

Henning Værøy

Harald Brauer
Synspunktene som fremkommer er uttrykk for forfatternes private faglige meninger.

Pål Grøndahl (f. 1961) er ph.d. og psykologspesialist. Han er forsker ved Kompetansesenter for sikkerhets-, fengsels- og rettspsykiatri, Oslo universitetssykehus og praktiserer som rettspsykiatrisk sakkyndig.

Forfatter har fylt ut ICMJE-skjemaet og oppgir ingen interessekonflikter.

Cato Grønnerød (f. 1966) er dr.psychol. og førsteamanuensis ved Psykologisk institutt, Universitetet i Oslo.

Forfatter har fylt ut ICMJE-skjemaet og oppgir ingen interessekonflikter.

Ulf Stridbeck (f. 1949) er dr. juris og professor i strafferett ved Det juridiske fakultet, Universitetet i Oslo.

Forfatter har fylt ut ICMJE-skjemaet og oppgir ingen interessekonflikter.

Henning Værøy (f.1955) er dr.med. og spesialist i psykiatri. Han er seniorforsker ved Avdeling for psykiatrisk forskning og fagutvikling, Akershus universitetsykehus, og arbeider som rettspsykiatrisk sakkyndig.

Forfatter har fylt ut ICMJE-skjemaet og oppgir ingen interessekonflikter.

Harald Brauer (f. 1969) er spesialist i psykiatri og jobber som seksjonssjef og avdelingsoverlege ved akuttpsykiatrisk avdeling. Akershus universitetssykehus. Han praktiserer som rettspsykiatrisk sakkyndig

Forfatter har fylt ut ICMJE-skjemaet og oppgir ingen interessekonflikter.

\section{Litteratur}

1. Pål Grøndahl. For dårlige betingelser for norsk rettspsykiatri. Dagsavisen 14.5. 2012. www. dagsavisen.no/nyemeninger/pgroendal/ (23.6.2012)

2. Grøndahl P. Scandinavian forensic psychiatric practices-an overview and evaluation. Nord J Psychiatry 2005; 59: 92-102.

3. Syse A. Strafferettslig (u)tilregnelighet - juridiske, moralske og faglige dilemmaer. Tidsskrift for Strafferett 2006; 6, nr. 3: 141-75.

4. Thorvik A. Frihet som medisinsk problem - rettspsykiatri i filosofisk lys. Tidsskr Nor Lægeforen 2000; 120: 2154-8.

5. Kirkebøen G. Skjønn, formler og klinisk praksis: Hvorfor vurderer erfarne klinikere så dårlig enda de vet så mye? Tidsskr Nor Psykologforen 1999; 36: $523-36$

Mottatt 31.5. 2012, første revisjon innsendt 20.6. 2012, godkjent 29.6. 2012. Medisinsk redaktør Merete Kile Holtermann. 